\title{
Processes of believing: Where do they come from? What are
} they good for? [version 1; peer review: 2 approved, 1 approved with reservations]

\author{
Rüdiger J. Seitz ${ }^{1}$, Raymond F. Paloutzian², Hans-Ferdinand Angel ${ }^{3}$ \\ ${ }^{1}$ Heinrich-Heine-University Düsseldorf, LVR-Klinikum Düsseldorf, Düsseldorf, Germany \\ 2Westmont College, St. Barbara, USA \\ ${ }^{3}$ Institute of Catechetic and Pedagogic of Religion, Karl Franzens University Graz, Graz, Austria
}

V1 First published: 25 Oct 2016, 5:2573

https://doi.org/10.12688/f1000research.9773.1

Latest published: 17 Jan 2017, 5:2573

https://doi.org/10.12688/f1000research.9773.2

\section{Abstract}

Despite the long scholarly discourse in Western theology and philosophy on religion, spirituality, and faith, explanations of what a belief and what believing is are still lacking. Recently, cognitive neuroscience research addressed the human capacity of believing. We present evidence suggesting that believing is a human brain function which results in probabilistic representations with attributes of personal meaning and value and thereby guides individuals' behavior. We propose that the same mental processes operating on narratives and rituals constitute belief systems in individuals and social groups. Our theoretical model of believing is suited to account for secular and non-secular belief formation.

\section{Keywords}

Belief, belief systems, behavior , credition, cerebral networks , meaning making, narratives, rituals, representations, perception , prediction, religion, valuation

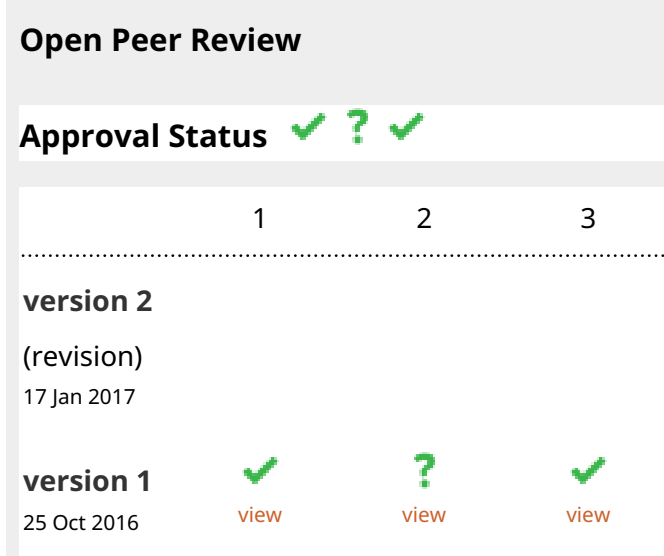

1. Motoaki Suguira, Tohoku University, Sendai, Japan

2. Peter W. Halligan, Learned Society of Wales (LSW) , Cardiff, UK

Michael H. Connors, Macquarie University, Sydney, Australia

3. Tatjana Schnell, University of Innsbruck, Innsbruck, Austria

Roberto Viviani, Innsbruck University, Innsbruck, Austria University of UIm, UIm, Germany Any reports and responses or comments on the article can be found at the end of the article. 
Corresponding author: Rüdiger J. Seitz (Seitz@neurologie.uni-duesseldorf.de)

Competing interests: No competing interests were disclosed.

Grant information: This work was supported by funds of the City of Graz, Austria, to the Credition Project.

Copyright: @ 2016 Seitz RJ et al. This is an open access article distributed under the terms of the Creative Commons Attribution License, which permits unrestricted use, distribution, and reproduction in any medium, provided the original work is properly cited.

How to cite this article: Seitz RJ, Paloutzian RF and Angel HF. Processes of believing: Where do they come from? What are they good for? [version 1; peer review: 2 approved, 1 approved with reservations] F1000Research 2016, 5:2573

https://doi.org/10.12688/f1000research.9773.1

First published: 25 Oct 2016, 5:2573 https://doi.org/10.12688/f1000research.9773.1 


\section{Summary}

Although largely neglected in contemporary science, we will show that believing is a fundamental brain function on which individual and societal behavior is grounded.

\section{Introduction}

In this communication we address the neurophysiological and anthropological dimensions in the contemporary sciences of the largely neglected but nevertheless important phenomenon of believing. Explanations are proposed for the putative physiological and psychological implementations of the process in the human brain (i.e., where do beliefs come from?), and their functions (i.e., what are beliefs good for?). In sorting out the levels of building blocks and their functions, the neurophysiological processes underlying the behavioral process of believing that can be studied empirically in the individual are differentiated from more general belief system processes that operate in large collections of people such as communities and societies. It is nevertheless important to explore the relationship between what individuals believe and the processes by which they do so and the more over-arching belief systems in a society. Fortunately, a new openness for understanding "religious phenomena" including "believing" as human abilities and activities is emerging (Connors \& Halligan, 2015; Krueger \& Grafman, 2013).

\section{A brief history of belief and believing}

Since the time of the great Greek philosophers Plato and Aristotle, the issue of what a belief is and how beliefs are related to knowledge and rationality has been a fundamental issue in Western philosophy. It raises the question of how to best understand the relation between knowledge and belief (Armstrong, 1973; Helm, 1999). Later, the writings of Saint Paul and other texts in the Christian Bible emphasized the importance of belief for understanding the role and meaning of Jesus Christ. Thus, in the history of Western thinking religious beliefs became more and more integrated into a dogmatic set of that what might be called "the Christian belief".

After the Enlightenment, religious truth claims became suspect. By the $20^{\text {th }}$ century under the widespread influence of psychoanalytic theory (Freud, 1928), religion was considered as an obsessional neurosis and "belief" negatively interpreted as a sign of human weaknesses. Thus, in psychology, religious phenomena including beliefs have from time to time been interpreted as deviant or at least as unneeded and subordinated under pathological labels such as neuroticism (Hills et al., 2004). A consequence is that there have been few attempts to empirically study the phenomenon of belief or to conceptualize "normal" belief on a scientific basis (Connors \& Halligan, 2015). Unfortunately, the "cognitive turn" in psychology, which occurred around 1960, did not succeed in making conscious the specific feature and relevance of "believing" as cognitive ability of humans. Nevertheless it opened the door to examining a wide range of cognitive processes such as thinking, meaning making, and perception and prepared psychology to integrate the believing process into further research. Recently, there has been increased interest in scientific discourse as well as in the general public in the nature of human belief. For example, in current psychology of religion there is increasing interest in belief and disbelief for both religious and atheist orientations (Bullivant \& Ruse, 2013; Schnell \& Keenan, 2011) and in the relationship between religiousness and specific religious beliefs to spirituality and health
(Koenig et al., 2012). This interest includes extensive and recently intensified debates about the meaning and utility of concepts such as faith, belief, transcendence, and spirituality (Oviedo, 2016; Paloutzian \& Park, 2013; Paloutzian \& Park, 2015; Visela \& Angel, 2016). In addition, in attempting to explore the neural correlates of religious experience, cognitive neuroscience implicitly implies that believing is a component of normal mental activity (Azari et al., 2001; Harris et al., 2009).

When we say holding a belief is a human ability, we mean that believing is envisioned as a mental activity generated by neural circuits in the brain (Boyer, 2003). Thus, a "normal belief" is a putative brain product of a believing individual and in general is entertained as a belief by humans. Beliefs serve a purpose in that they are linked to personal intuitive judgments about the subjective certainty of mental constructs and sensory perceptions (Harris et al., 2008). Personal beliefs thereby function as part of the building blocks of intelligent behaviour (Elliott et al., 1995; Howlett \& Paulus, 2015; Taves, 2015).

\section{The need for theory}

We need to formulate a theoretical concept for normal believing in order to integrate findings such as the above into a coherent framework. Of course, the issue of what constitutes "normal" must first be settled. In a philosophical sense there is no selfunderstanding concept that would explain terms like "normality," "norms," or "normative." Deep discussion of this issue is beyond the concerns of this paper, but we emphasize that normal belief is neither a pathological brain state nor strictly limited to religions. Nevertheless, to develop such an innovative understanding of "normal belief" requires some theoretical considerations, as follows.

A) In psychology of religion, belief is often understood as a religious phenomenon. However, a concept of "normal belief" does not equal religious belief because people believe all manner of things, most of which are a-religious. Thus "belief" has to be understood generically, not only religiously. Consequently, "normal belief" is a proper characterization and is relevant for secular and religious domains.

B) As a noun, "belief" is defined in different ways. Often it is treated as a "state" (Churchland \& Churchland, 2013) or as an attitude towards someone or something, such as liking and favoring a person or disliking and seeing only the negative side of an issue. In contrast, in understanding "belief" as a mental activity generated by neural circuits in the human brain, we emphasize the procedural character of belief: it is not a state; believing is a mental process. When understood this way, the notion of belief can be dissociated from concepts with static meanings, which are usually expressed in substantive terms like "belief," "faith," or "spirituality".

C) A model of the believing process, which is inherently a procedural concept, has to account for how a concept that inherently includes fluctuation relates to "beliefs" that we perceive as more static. How the fluidity of the believing process is related to our perception of belief stability has to be integrated into the model of normal believing. 
In addition to this itself being illuminating, it will provide a new approach to topics such as the "formation of belief" and maintaining "belief systems" (Langdon \& Coltheart, 2000).

D) A concept of a "normal process of believing" has to integrate the complex notions of "time" and "process". In philosophy, the understanding of time has been broadly reflected since antiquity and still is widely discussed (Le Poidevin \& McBeath, 1993), indicating that it cannot be reduced to merely "measuring" time or time being a "measurable" variable or property. Similarly, process thinking has a long tradition in Western philosophy, start-

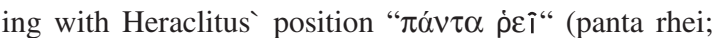
everything flows) and developed in the field of process philosophy as spawned in the writings of Bergson, Merleau-Ponty, and especially Whitehead indicating that process constitutes change and occurs through and interacts with time.

E) A full account of the believing process has to explain what happens from the time the process starts until it comes to closure. This explanation needs to include an account of the subliminal aspects of the process.

\section{From neuroscientific to anthropological dimensions of believing}

Advances in the natural sciences have made it possible to scientifically explore to a certain degree virtually all physiological processes enabling human life. Analogous to the physical sciences, the life sciences seek to construct simplified models of biological processes that can be tested empirically by appropriate experiments. This approach was adopted by cognitive neuroscience with the aim of identifying fundamental processes underlying human behavior. There are four levels of exploration in this enterprise.

A) There is a hermeneutic level rooted in philosophical issues. Cognitive neuroscience uses terms that come from different philosophical traditions and have their own history of meaning. We need to clarify which terms are most adequate to shape the theoretical paradigm of neuroscientific research and to reflect its findings. For example, the terms "process", "relevance", "imagination", "meaning", "value", and "evidence" are less clear for cognitive neuroscience purposes (and, therefore, are shaped to indicate specific, technical meanings) as they might appear in everyday speech. Such attaching of technical meanings to everyday words is often necessary and a normal part of doing science.

B) The so-called linguistic turn in philosophy had sensible implications for the use of language. Even our everyday phrases such as "to think," "to know," or "to do" imply a connection to reality. We cannot avoid terms of this sort in this paper, but space constraints do not allow for philosophical discussion of their use. Suffice it to say that the terminology used in this field, especially when distinguished from the language of folk psychology, includes their relation to reality as a key aspect.
C) There is the behavioral level, which can be accounted for by heuristic cognitive models. By empirical research, models of this sort have been validated as, for example, the multimodal networks of memory, attention, and language (Levelt, 1993; Mesulam, 1990).

D) Modern neurophysiological methods such as functional imaging and electroencephalographic techniques allow us to explore the temporal order in which different brain areas are engaged during performance of specific behavioral tasks. Studies of this sort have yielded models of brain function in terms of both plausibility and topographic and temporal realization in the human brain. An example is the review on the recently widely debated issue of "free will" (Hallett, 2016).

We greatly expand the complexity of the psychological processes involved when individuals interact with their environment to understand what is going on around them. From birth onwards humans have to learn to analyze signals coming from the environment in order to behave appropriately in response to them (Seitz et al., 2009). Also, they must develop insight into their own sensory capacities and bodily strength, and rely on them. These capacities are linked to the concept of a bodily and mental identity combined with self-esteem and a sense of agency (Farrer \& Frith, 2002; Northoff, 2011). This linkage allows people to retain a high degree of subjective certainty even when the situation is objectively unclear.

We can observe events at a behavioral level but we have yet to learn what cognitive processes make for evaluative judgments at any level of specificity. Where do cognitive processes get the criteria they "use" to measure and evaluate internal and external stimuli? If we suppose the existence of a kind of "valuation system," it may be best and intellectually sound to consider it as one of several aspects of a meaning system. This is because the concepts of measuring and valuing are intimately linked through meaning. For example, what has positive meaning is also valued, and what is valued is or has been measured, which affords its meaning for the person. In fact, all of the recent scholarship on meaning systems either explicitly or implicitly includes values or valuing among the list of components of a meaning system (Markman et al., 2013; Park, 2005). Therefore, just as global meaning systems are psychological structures comprised of interactive components that guide the interpretation of and response to information, so also are "valuation systems" a component of meaning systems that interact with all the other components of meaning systems and contribute importantly to the operation of the whole system.

People combine formal analytic and subjective affective judgments to arrive at propositions of the form "I believe that ...". We assume that the basic processes of believing are universal but are also modulated by human individuality. For example, it has been shown that individuals differ in how they detect and interpret noisy optical signals, and some might be prone to magical ideation. In fact, magical ideation might influence the judgement of contingencies (Adelson, 1993; Brugger \& Graves, 1997).

Recently, processes of believing have been labelled "credition" (Angel, 2013). Credition is a neologism based on the Latin verb 
credere (to believe). The notion of credition is different from faith, religion, and spirituality, and provides an empirical psychophysiological framework for the study of what believing is at the psychological, neuroscientific, and social levels of analysis. Doing this involves multilevel data mapping (Paloutzian \& Park, 2013; Paloutzian \& Park, 2015) or bi-directionally "translating" the data and concepts from one level of analysis to an adjacent level of analysis in order to assess the degree to which they correspond. In outlining the heuristic model of credition, Angel \& Seitz (2016) summarized it to include cognitive and emotional operations affording believing. In particular, they presented correspondences between cognition, emotion, and credition operations and the neurophysiological processes of perception and valuation.

To understand the process of believing, it is essential to understand how people attribute personal meaning to specific sensory perceptions (Paloutzian \& Mukai, 2016; Seitz \& Angel, 2015). Two dynamic and reciprocal processes are at work to enable this.

(1) Perception deals with the formal characteristics of physical stimuli in the outside world (see Figure 1). The process employs sensory systems such as vision, audition, and somatosensation as well as higher order sensory information processing. The resulting representations comprehend feature identification, stereognosis, associations of pragmatic use, object-name associations, etc. This is a physical process that involves highly complex interactions between explorative movements and object perception and results in comprehending the object's features (Jeannerod, 1995; Roland \& Mortensen, 1987). Internal mental states effectively represent external states in a probabilistic fashion (Friston et al., 2014). As illustrated in research on unstable picture puzzles, objects become more identifiable against a noisy background when either the signal-to-noise ratio or the duration of exposure increases
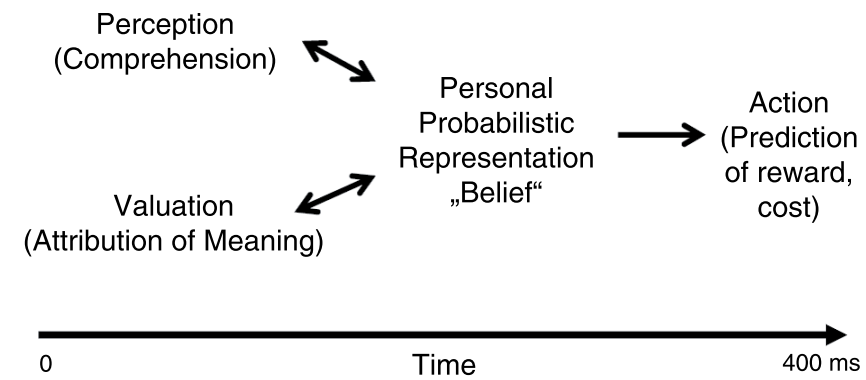

Figure 1. Mental operations underlying meaning making and guidance of behaviour in the probabilistic perception-actionvaluation model (after Seitz et al., 2009). Perception refers to the formal comprehension of external items and events; valuation affords the attribution of personal meaning to them. Both psychic functions operate in a dynamic and reciprocal fashion leading to personal probabilistic representations in the human brain. As the personal probabilistic representations are formed in milliseconds typically being implicit, they may become explicit owing to a high emotional loading and a repetitive exploration. The subsequent actions are based on the personal probabilistic representations being loaded with probabilistic predictions of reward and cost.
(Takei \& Nishida, 2010). Moreover, the physical characteristics of objects are processed such that the perceived composition of the components of an object is matched against that of a previously perceived item (Adelson, 1993). This process may distort the perception of the physical characteristics of the object but results in a meaningful illusion.

The speed with which sensory information is processed is important. Nervous tissue is exceptionally fast at doing so owing to the high excitability of nervous membranes, which allows for rapid inter-cell communication. High speed information processing is a phylogenetic advantage for control of behavior. Because of this high speed, most sensory information is processed non-consciously in the brain; only some bits of information enter consciousness. Accurate material categorization of real-world images occurs as fast as $30 \mathrm{~ms}$ but increases in accuracy with longer exposure times, up to $120 \mathrm{~ms}$ (Sharan et al., 2014; van Gaal et al., 2011). As soon as information reaches the primary visual cortex, early automatic processing in the $100 \mathrm{~ms}$ range affects information transmission further downstream (Nortmann et al., 2015). This feed-forward processing has the feature of predictive coding. For example, early responses in the amygdala ( 40 to $140 \mathrm{~ms}$ ) are unaffected by attentional load, while later responses $(280$ to $410 \mathrm{~ms}$ ) in the amygdala are modulated by attention (Kuo et al., 2009).

The perception of objects has many commonalities with the perception of events, but there are also clear differences (Radvansky \& Zacks, 2014). The most important difference is that objects are static entities, whereas events are fluid and evolve over time. Accordingly, events are perceived from a succession of patterns in which items of interest change over time in a coherent manner. Thus, an event becomes a meaningful percept by temporal coding. As an example, in the virtual reality environment the impression of a ball moving towards the observer is generated by the increasing size of the ball against a static background (Cameirão et al., 2010). Similarly, the movement of a ball between two persons in a virtual landscape generates the impression that the two people are throwing a ball to each other. Thus, the observer constructs a meaning and attributes it to the observed temporally evolving events. Other examples of temporal coding of events include the processes involved in writing, reading, and playing and listening to music. Again, decoding of the temporal sequence of single events provides the meaning of the events. In fact, the rapid temporal evolution of the electrical activity in the peripheral nerves recorded during hand writing can be played back to the nerves and shown to be capable of producing the same limb movements (Aimonetti et al., 2007).

(2) In addition, a dynamic and reciprocal process is concerned with processing the affective value of physical stimuli in the outside world and attributing person-specific meaning to them (Figure 1). The personal probabilistic representations that result from these processes are typically implicit but can become explicit when the stimuli trigger high personal meaning (Friston et al., 2014). Prominent negative features of this sort are signals of potential harm or threat; prominent positive features may be signals of beauty or pleasantness (Rolls, 2006). Such affective labeling is behaviorally highly relevant because it may evoke opposite motivations and responses, such as avoidance or desire. 
Objects of special relevance for humans are human faces, since facial expressions of emotion characterize interpersonal encounters and induce meta-analytic processes leading to the interpretation of the mental as well as the emotional state of the counterpart (Potthoff \& Seitz, 2015). As in the case of identification of other objects, these processes are fast; they take place within $40 \mathrm{~ms}$, as is evident from behavioral and neurophysiological studies (Bar et al., 2006; Smith, 2012). In a more general sense, one may wonder how subjective categories such as aesthetic judgments become important. Pertinent to this issue, it has been shown that individual aesthetic preferences for faces are shaped by an environment associated with an individual -- not by genes, as found in judgments of attractiveness in over 570 monozygotic twins (Germine et al., 2015).

Finally, repeated experience with the same environmental objects or events stabilizes their cognitive-emotional representations so that, e.g., familiarity with an object or information promotes learning about it and increases a sense of trust in the object or information (Chang et al., 2010; d'Acremont et al., 2013; Henkel \& Mattson, 2011). In addition, representations already formed will be updated as new items and information are accommodated to the store of acquired knowledge. Also, there is recent evidence that learning is accompanied by subjective emotional loading. For example, learning invokes a sense of confidence that increases in proportion to the number of observations of a task as well as task performance (Meyniel et al., 2015).

Perceived information is what motivates the generating of actions (Figure 1). Generating actions involves intentions to act, action selection, inhibition of unwanted acts, and predicting reward and costs of acts (Nachev et al., 2008; Passingham et al., 2010). In general terms, this refers to deciding what to do next. The neuroscientific basis for decision making has been shown to be related to reward valuation (Grabenhorst \& Rolls, 2011) and unconscious or intuitive selection that evolves within far less than $400 \mathrm{~ms}$ (Chen et al., 2010; Kahnt et al., 2010; Schultze-Kraft et al., 2016). The processes that regulate the performance of actions are replete with probabilistic reward and cost predictions determined by the personal meanings attributed to the mental representations of the signals from the outside world (Friston et al., 2014). The actionperception-valuation triad has been postulated to account, in context of a hierarchical dimension, for computations of physical, social, and cultural matters (Sugiura et al., 2015).

\section{Functional anatomy of the believing process}

Valuation of perceived information and making attributions intimately involves the medial frontal cortex (Grabenhorst \& Rolls, 2011; Kahnt et al., 2010; Seitz et al., 2006; \& van Overwalle, 2009). This is also true for attributions about the mental states of others (Bird \& Viding, 2014; Kanske et al., 2015). The dorsolateral prefrontal cortex is specifically involved in making attentive decisions (Gray et al., 2002; Niendam et al., 2012). These psychological processes include valuation of delayed reward and engage extensive brain circuits including the medial and lateral prefrontal cortex (Niendam et al., 2012; Peters \& Büchel, 2009; Thompson \& Duncan, 2009). The activation of the dorsolateral prefrontal cortex during decision processes was correlated with gamma-activity and found to be related to the capacity of the working memory system and fluid intelligence scores (Federenko et al., 2013; Roux et al., 2012). There is recent experimental evidence that believing can also affect activity in these brain areas (Howlett \& Paulus, 2015; Ninaus et al., 2013). As dopaminergic midbrain areas are tightly connected with these areas and encode shifts in beliefs, they may contribute to belief updating (Schwartenbeck et al., 2016). This means that the control of a person's behavior is mediated by extensive neural networks that include the medial and dorsolateral prefrontal cortex related to comprehension of the formal sensory information and to emotional valuation of that information. As a model of the believing process we studied understanding other people's behaviour in terms of most probable explanations using multidimensional functional magnetic resonance imaging (fMRI). The set-up of the experiment summarized in Figure 2 (an event-related fMRI study) allowed us to separate a pre-decision phase in which emotional information was presented, from the phase when the subjects were

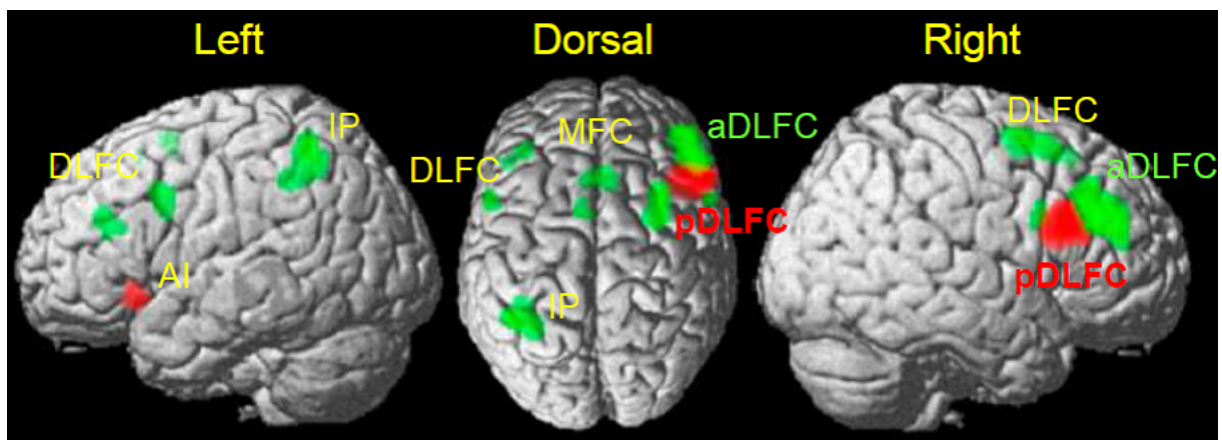

Figure 2. Non-overlapping cortical networks involved in decisions based on inferential beliefs about subliminal information. Red areas were functionally connected to activation of the posterior dorsolateral prefrontal cortex (pDLFC) during empathic evaluation in the predecision phase. The right pDLFC was connected with the left anterior insula (AI). Green areas belonged to a widespread network involving the anterior dorsolateral prefrontal cortex (aDLFC) which was activated related to verbal processing in the actual decision phase. The right aDLFC was connected to the right and left dorsolateral prefrontal cortex (DLFC), the mediodorsal prefrontal cortex (MFC), and the left inferior parietal lobule (IP). Note, that masking of the subliminal $(40 \mathrm{~ms})$ visual stimulus required the subjects to make a decision according to what they believed was the right answer. Further details in Prochnow et al. (2015). 
required to make their decision on verbal material. Since the information on which the decisions had to be based was presented only below the level of awareness, the subjects were put in a state of uncertainty. This is a situation in which it is typical for someone to rely on what he or she already believes to be correct.

The figure shows that two different functional circuits including the brain areas described above. In addition, these circuits included the supplementary motor area (SMA) in the dorsal portion of the medial frontal cortex that provides the link to proactive movement control by adjusting the level of motor readiness affording response inhibition (Chen et al., 2010; Meder et al., 2016) as well as free choice movement coding and behavioral tactics (Matsuzaka et al., 2016; Passingham et al., 2010). Meta-analytic studies of functional neuroimaging data have revealed that different nodes in the medial frontal cortex, including the SMA and pre-SMA, are involved in the proactive and inhibitory control of actions (Seitz et al., 2006; van Overwalle, 2009). The neural hubs identified in these studies were arranged in a caudo-rostral gradient of increasingly more abstract information processing. As evident from resting state connectivity, the medial cortical areas and the parietal cortex were shown to be part of the so-called default mode perspective of humans (Gusnard et al., 2001).

Prospective valuation of rewards in a familiar context was reported to be related to activation of key nodes of emotional and autobiographical memory retrieval and dynamically modulated by frontalstriatal connectivity (Sasse et al., 2015). The modulation of cortical information by processing in trans-striatal relay loops has been described as of key importance for learning routines and rules as well as their combinations (Graybiel \& Grafton, 2015). Accordingly, the multiplex aspect of probabilistic cognitive-emotional representations involves cortical and subcortical networks. In effect, these data support the notion that believing in personal probabilistic representations is a normal brain function.

\section{Belief systems}

In initiating this scientific examination of believing and belief systems, several distinctions in the meanings of key terms must be kept in mind. For example, in addition to "belief" too often assumed to connote something religious or spiritual, it has also too often been assumed that issues of belief do not concern people who are nonreligious or generically secular (Stich, 1996). Sometimes it is assumed that they don't have any beliefs (Bullivant \& Ruse, 2013). But social science research documents that believing abounds in such persons even though the content differs from that in typical religious beliefs (Schnell \& Keenan, 2011). Further, the meanings of specific terms should be meticulously teased apart in order to avoid confusion. For example, because "religion" is not one thing but many, it is better to talk about specific religions, because almost no statement about what "religion" does will hold for all of them (Paloutzian \& Park, 2013). And it is circular to define religion with reference to "the sacred" or as the "search for significance in ways related to the sacred" (Pargament, 1992) because anything can be significant (i.e., matter to someone) and literally anything, including a rock, idea, or war, can be attributed the property of sacrality. Above that it is important to acknowledge that "religiosity" and "religion" are not the same. For example, various and even contradictory expressions of religiosity may be associated with a given religion. Moreover, "religiousness" connotes the processes that mediate how one appropriates and manifests one's religion in life, not "the religion" as such (whatever "the religion" might "really" mean).

Theoretically, "religious experience" cuts across most of the above constructs, in addition to being manifest in both the individual and collective realms. But "experience" is a phenomenologically private sphere. It is not a matter of public knowledge even though the claims, words, and behaviors associated with purported experiences are. For reasons such as these, "religion" explains little about how individuals make use of religion when fostering their "religiosity." For instance, some may integrate their religion into their worldview in a more peaceful and harmonious way, while others may do it in a more aggressive or aversive manner. Likewise, for some, adopting one specific version of one religion is the key to this life and a life in the hereafter, whereas for others anything or nothing will do just fine. For some, William James' (1985) emphasis on "religious experience" constitutes the defining moment of a life. In contrast, it has recently been argued that humans are born with an "implicit religiosity" (Schnell, 2003) and that they are "born believers" (Barrett, 2012). These ideas suggest that humans come automatically equipped to engage in the process of believing many things -- whether secular or religious, or ordinary and mundane vs. lofty and idealized. That such objects of belief become incorporated into over-arching belief systems is consistent with the accumulating empirical evidence that the human proclivity toward worldview construction can be conceptualized as a by-product of normal human cognitive processes (Boyer, 2003; Kapogiannis et al., 2009).

The raw phenomenological mental representations in a person's mind are not accessible to scientific exploration; thus their veridicality in the purest sense is neither provable nor disconfirmable. They constitute personal beliefs (i.e., meanings made) that can be characterized as falling into two general categories. First, there are beliefs that everyone in a group or society will hold, such as the belief that they all see an apple sitting on the table and that they can eat it and it will taste good. Beliefs of this sort have been addressed earlier and are subject to some degree of public verifiability. Second, there are beliefs apparently unique to one person, such as someone being certain that he or she saw God and heard God's voice - a report not subject to public verification. Either way, we engage in a functional inherent valuation process that involves focusing attention on the incoming information in a dynamic bottom-up-top-down fashion, the result of which forms our probabilistic accounts and beliefs about what is observed in the outside world (Wiese et al., 2014). Thus, beliefs of individuals are created by mental processes that involve perception, attention, valuation, and storage as well as up-dating of information as described in detail in the previous part of this communication.

Given the above, it is obvious that religious-related and beliefrelated words can become easily conflated and cause great confusion. To explain this confusion and help avoid some of it, let us probe simple language expressions commonly used in everyday circumstances. When someone says, "I believe God is the creator of the world," they are stating a subjective proposition that cannot be empirically verified. Not uncommonly, the person 
becomes emotionally upset upon hearing others question or negate the statement. Similarly, the statement "I believe this is so and so" expresses a person's subjective perspective that the observed fact or event has only a limited degree of certainty for him or her. The statement is similar to "I think this is so and so" but, in contrast, reflects the person's higher degree of certainty on which he or she builds an emotional inclination to defend this stance. This is probably because people's intuitive belief system appears to represent beliefs as either true or false rather than on an uncertainty gradient (Johnson et al., 2015). Moreover, beliefs activated by cues can profoundly affect behaviour, as has been found for gaze and other behaviors similar to those that respond to primes (Kristjansson \& Capana, 2010; Wiese et al., 2014). Conversely, hypnotic suggestion can be seen as a form of inducing an imagination that is temporarily accepted as if it is believed, since hypnosis can exert profound changes on a person's mood, thoughts, perceptions, and behaviour (Halligan \& Oakley, 2014). Consequently, we assume that personal probabilistic representations form the knowledge system of an individual displaying a high degree of momentary subjective relevance.

As people grow up and are imbedded in social groups, successful communication is fundamental to the exchange of meanings of perceptions, imaginations, and mental states. Thus, group evolution in addition to, not in place of, the evolution of individuals becomes important. Owing to the wealth of information to which each individual is confronted every day, information is communicated from person to person by language. Language is characterized by the human capacity to combine meaningful units into an unlimited variety of larger structures, each differing systematically in meaning. The capacity to generate a limitless range of meaningful expressions from a hierarchical structure of finite elements differentiates human language from all other animal communication systems (Fitch \& Hauser, 2004). This means that the most complete understanding of the processes of believing and communicating among humans requires that we examine the processes from micro to macro levels within a multilevel interdisciplinary paradigm (Emmons \& Paloutzian, 2003). In this instance, the intersection of anthropology and neuroscience can help us understand the relationships between the socio-cultural contexts in which people live and human brain function (Keysers \& Gazzola, 2010; Vogeley \& Roepstorff, 2009).

Individuals are constantly faced with boundaries imposed by the surrounding people. There are universal dimensions of interpersonal and pergroup social cognition that guide the individual's behavior (Fiske et al., 2007). Thus, living in a society requires the generation of systems of probabilistic representations that are similar across individuals and exhibit a liability for communities as they give meaning to people's collective work. As detailed by Schnell (2012), narratives typically taught implicitly and explicitly in families and schools provide the historical and identity-relevant background information for social groups, through passive listening as well as active reading and reciting. Thereby, narratives provide the formal content of belief systems (Figure 3).

Narratives constitute a mental construct or meaning for the history of a community or society as well as for occasions of festive events throughout the year. People may be repeatedly exposed to a narrative (e.g., at annual special events); this affords them an opportunity to comprehend their meaning and learn them by heart. Acceptance of the narratives is strengthened as people participate in group rituals, which involve defined actions whose performance within a community or society leads to highly predictive experience by their members (La Cour \& Hvidt, 2010; Seligman \& Brown, 2010). Through such group activities, emotional value and personal meaning is attributed to the belief systems (Figure 3). Looked at from a more molecular level of analysis, the psychophysical and neurophysiological processes affording the internalization of narratives and rituals in the individuals have been summarized above.

People in communities and societies may be similar in their belief systems due to exposure to virtually identical narratives and rituals. Rituals play a key role in stabilizing beliefs owing to their standardized practice and regular repetitions at a present moment or more importantly at regular times each year. This is mediated by high fidelity imitation that mediates conventional learning (Legare \& Nielsen, 2015). Because rituals are rooted in narratives or myths that refer to the past, even beyond the limits of personal experience, their regular repetition produces the feeling of familiarity, high predictability, reward and transcendence. They can constitute the experience and knowledge and, thereby, the belief systems of individuals from childhood onwards (Seligman \& Brown, 2010). With this background, the individual's experience gets linked to narrative knowledge through instruction and/or associative learning - which is extremely powerful because it may take only one to two repetitions (Blechert et al., 2016). In addition, the combination of the verbal and pragmatic information generates trust in the promise provided by the narratives, strengthening people against perceived threats, even to their physical integrity (Boyer \& Liénard, 2006). Ultimately, it leads to the inference of
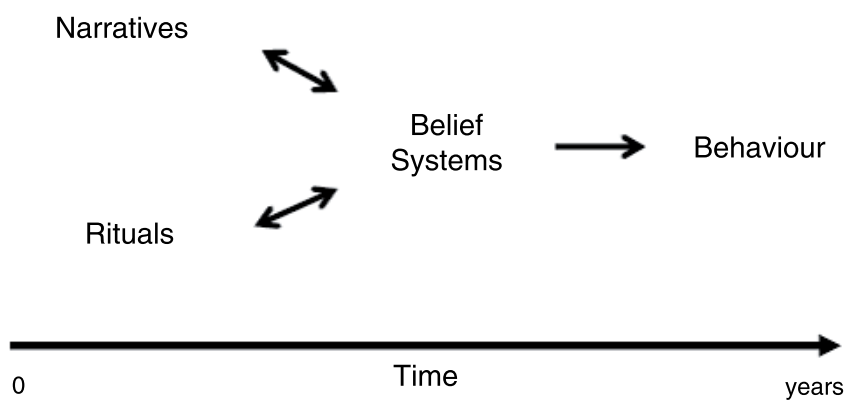

Figure 3. Formation of belief systems and their behavioral consequences as predicted by the probabilistic perceptionaction-valuation model. Narratives are socially transmitted in communities with many repetitions and ramifications in colloquial and formal settings enabling individuals to comprehend their contents. Similarly, socially practiced rituals allow for attribution of personal meaning to the belief systems. Importantly, subjects may be exposed to both sources repetitively over many years internalizing their meaning by dedicated and reciprocal psychophysical processes that lead to complex probabilistic representations, i.e. belief systems. These belief systems are similar among individuals who belong to the same social group or society. The subsequent behavior of the individuals is loaded with probabilistic predictions about their future, termed hope and fear. 
moral and ethical standards that are derived from such narratives and limits the possible actions to be selected (Mesulam, 2008).

Nevertheless, belief systems have a personal aspect that reflects the experience, attitudes, and personality of the individual. As experience changes over time, belief systems are likely to change as well. In addition, each individual has a unique intuitive experience of the world. For example, intuitive beliefs may originate from the naive but nevertheless fundamental dualistic experience of the surrounding immanent physical world and the seemingly immaterial sky. They can be a powerful component of an individual's belief system. Belief systems include the individuals' implicit or explicit answers (or attempts at such) on how to cope with the future, and how to provide existential meaning whether secular, spiritual, or religious (La Cour \& Hvidt, 2010). They also address other issues such as what values to hold, what priorities to live by, and what is ultimately most important. The predictions for the future are probabilistic; they may provide hope of reward or fear of punishment depending on how one has lived (Figure 3). Also, depending on the promises of a particular belief system, the individual may be in a position to anticipate his or her future in a way most suited to his or her preference. At a neurophysiological level, it was shown that the cultural self-construal mind-set involves parieto-frontal brain areas including the medial frontal cortex as described above for spontaneous evaluation and behavioral control (Leuthold et al., 2015; Wang et al., 2013).
Overall, we are beginning to understand one of the most fundamental processes that enable humans to be human - the process of believing. We suggest that the mental processes described in this paper represent fundamental human brain functions that transform cognitive and emotional perspective taking into account personal perspective making, i.e., into views of secular and non-secular transcendence. One limitation of the concept of believing as presented here is that it is rooted in Western thinking, especially in the English language. Although beliefs and believing can have different connotations in various religions and cultural environments (Angel \& Seitz, 2016), our model can nevertheless generate a diversified but collaborative discussion on how to relate empirical data to science-based models of believing.

Author contributions

RJS wrote and edited the manuscript and designed the figures.

HFA and RLP contributed to its content and edited the manuscript.

\section{Competing interests}

No competing interests were disclosed.

Grant information

This work was supported by funds of the City of Graz, Austria, to the Credition Project.
Adelson EH: Perceptual organization and the judgment of brightness. Science. 1993; 262(5142): 2042-2044.

PubMed Abstract | Publisher Full Text

Aimonetti JM, Hospod V, Roll JP, et al:: Cutaneous afferents provide a neuronal population vector that encodes the orientation of human ankle movements. J Physiol. 2007; 580(Pt. 2): 649-658.

PubMed Abstract | Publisher Full Text | Free Full Text

Angel HF: Credition. In: Runehov, ALC, Oviedo L, Azari NP. (eds) Encyclopedia of Sciences and Religion. Springer Reference, Dordrecht. 2013; 1: 536-539. Publisher Full Text

Angel HF, Seitz RJ: Process of believing as fundamental brain function: the concept of credition. SFU Research Bulletin. 2016; 3: 1-20.

Publisher Full Text

Armstrong DM: Belief, truth, and knowledge. Cambridge: Cambridge University Press; 1973

Reference Source

Azari NP, Nickel J, Wunderlich G, et al:: Neural correlates of religious experience. Eur J Neurosci. 2001; 13(8): 1649-1652.

PubMed Abstract | Publisher Full Text

Bar M, Neta M, Linz H: Very first impressions. Emotion. 2006; 6(2): 269-278. PubMed Abstract | Publisher Full Text

Barrett JL: Born believers: The science of children's religious belief. New York: Atria Books. 2012.

Reference Source

Bird G, Viding E: The self to other model of empathy: providing a new framework for understanding empathy impairments in psychopathy, autism, and alexithymia. Neurosci Biobehav Rev. 2014; 47: 520-532.

PubMed Abstract | Publisher Full Text

Blechert J, Testa G, Georgii C, et al: The Pavlovian craver: Neural and experiential correlates of single trial naturalistic food conditioning in humans. Physiol Behav. 2016; 158: 18-25.

PubMed Abstract | Publisher Full Text
Boyer P: Religious thought and behaviour as by-products of brain function. Trends Cogn Sci. 2003; 7(3): 119-124.

PubMed Abstract | Publisher Full Text

Boyer $\mathrm{P}$, Liénard $\mathrm{P}$ : Why ritualized behavior? Precaution Systems and action parsing in developmental, pathological and cultural rituals. Behav Brain Sci. 2006; 29(6): 595-613; discussion 613-50.

PubMed Abstract | Publisher Full Text

Brugger P, Graves RE: Testing vs. Believing Hypotheses: Magical Ideation in the Judgement of Contingencies. Cogn Neuropsychiatry. 1997; 2(4): 251-72. PubMed Abstract | Publisher Full Text

Bullivant S, Ruse M: The Oxford Handbook of Atheism. Oxford: Oxford University Press. 2013.

Publisher Full Text

Cameirão MS, Badia SB, Oller ED, et al: Neurorehabilitation using the virtual reality based Rehabilitation Gaming System: methodology, design, psychometrics, usability and validation. J Neuroeng Rehabil. 2010; 7: 48. PubMed Abstract | Publisher Full Text | Free Full Text

Chang LJ, Doll BB, van 't Wout M, et al.: Seeing is believing: trustworthiness as a dynamic belief. Cogn Psychol. 2010; 61(2): 87-105.

PubMed Abstract | Publisher Full Text

Chen X, Scango KW, Stuphorn V: Supplementary motor area exerts proactive and reactive control of arm movements. J Neurosci. 2010; 30(44): 14657-14675. PubMed Abstract | Publisher Full Text | Free Full Text

Churchland PS, Churchland PM: What are Beliefs? In: Krueger F, Grafman J (eds), The neural basis of human belief systems. Psychology Press, Hove, 2013; 1-17. Reference Source

Connors MH, Halligan PW: A cognitive account of belief: a tentative road map. Front Psychol. 2015; 5: 1588.

PubMed Abstract | Publisher Full Text | Free Full Text

d'Acremont M, Schultz W, Bossaerts P: The human brain encodes event frequencies while forming subjective beliefs. J Neurosci. 2013; 33(26): 10887-10897.

PubMed Abstract | Publisher Full Text | Free Full Text 
Elliott R, Jobber D, Sharp J: Using the theory of reasoned action to understand organizational behaviour: The role of belief salience. Br J Soc Psychol. 1995; 34(2): 161-172.

Publisher Full Text

Emmons RA, Paloutzian RF: The psychology of religion. Annu Rev Psychol. 2003; 54: 377-402.

PubMed Abstract | Publisher Full Text

Farrer $C$, Frith $C D$ : Experiencing oneself vs another person as being the cause of an action: the neural correlates of the experience of agency. Neuroimage. 2002; 15(3): 596-603

PubMed Abstract | Publisher Full Text

Federenko E, Duncan J, Kanwisher N: Broad domain generality in focal regions of frontal and parietal cortex. Proc Natl Acad Sci U S A. 2013; 110(41): 16616-16621. PubMed Abstract | Publisher Full Text | Free Full Text

Fiske ST, Cuddy AJ, Glick P: Universal dimensions of social cognition: warmth and competence. Trends Cogn Sci. 2007; 11(2): 77-83.

PubMed Abstract | Publisher Full Text

Fitch WT, Hauser MD: Computational constraints on syntactic processing in a nonhuman primate. Science. 2004; 303(5656): 377-380.

PubMed Abstract | Publisher Full Text

Freud S: The future of an illusion. Translation from German by Robson-Scott WD, Strachey J. Hogarth Press, London; 1928.

Reference Source

Friston K, Sengupta B, Auletta G: Cognitive dynamics: from attractors to active inference. Proc IEEE. 2014; 102(4): 427-445.

Publisher Full Text

Germine L, Russell R, Bronstad PM, et al:: Individual Aesthetic Preferences for Faces Are Shaped Mostly by Environments, Not Genes. Curr Biol. 2015; 25(20): 2684-9.

PubMed Abstract | Publisher Full Text | Free Full Text

Grabenhorst F, Rolls ET: Value, pleasure and choice in the ventral prefrontal cortex. Trends Cong Sci. 2011; 15(2): 56-67.

PubMed Abstract | Publisher Full Text

Gray JR, Braver TS, Raichle ME: Integration of emotion and cognition in the lateral prefrontal cortex. Proc Natl Acad Sci U S A. 2002; 99(6): 4115-4120. PubMed Abstract | Publisher Full Text | Free Full Text

Graybiel AM, Grafton ST: The striatum: where skills and habits meet. Cold Spring Harb Perspect Biol. 2015; 7(8): a021691.

PubMed Abstract | Publisher Full Text

Gusnard DA, Akbudak E, Shulman GL, et al: Medial prefrontal cortex and selfreferential mental activity: relation to a default mode of brain function. Proc Natl Acad Sci U S A. 2001; 98(7): 4259-4264.

PubMed Abstract | Publisher Full Text | Free Full Text

Hallett M: Physiology of Free Will. Ann Neurol. 2016; 80(1): 5-12.

Publisher Full Text

Halligan PW, Oakley DA: Hypnosis and beyond: exploring the broader domain

of suggestion. Psychology of Consciousness: Theory, Research, and Practice.

2014; 1(2): 105-122.

Publisher Full Text

Harris S, Kaplan JT, Curiel A, et al.: The neural correlates of religious and nonreligious belief. PLOS One. 2009; 4(10): e0007272.

PubMed Abstract | Publisher Full Text | Free Full Text

Harris S, Sheth SA, Cohen MS: Functional neuroimaging of belief, disbelief, and uncertainty. Ann Neurol. 2008; 63(2): 141-147.

PubMed Abstract | Publisher Full Text

Helm P: Faith and Reason. Oxford University Press, Oxford; 1999.

Reference Source

Henkel LA, Mattson ME: Reading is believing: the truth effect and source of credibility. Conscious Cogn. 2011; 20(4): 1705-1721.

PubMed Abstract | Publisher Full Text

Hills P, Francis LJ, Argyle M, et al:: Primary personality trait correlates of religious practice and orientation. Pers Indiv Differ. 2004; 36(1): 61-73.

Publisher Full Text

Howlett JR, Paulus MP: The neural basis of testable and non-testable beliefs PLoS One. 2015; 10(5): e0124596.

PubMed Abstract | Publisher Full Text | Free Full Text

James W: The varieties of religious experience: A study in human nature.

Cambridge MA, Harvard University Press (Original work published in 1902); 1985. Reference Source

Jeannerod M: Mental imagery in the motor context. Neuropsychologia. 1995; 33(11): 1419-1432.

PubMed Abstract | Publisher Full Text

Johnson SGB, Merchant T, Keil FC: Predictions from uncertain beliefs

In: Noelle DC, Dale R, Warlaumont AS, Yoshimi J, Matlock T, Jennings CD,

Maglio PP (Eds.), Proc 37th Ann Conf Cogn Sci Soc. Austin, TX: Cogn Sci Soc;

2015; 1003-1008.

Reference Source

Kahnt T, Heinzle J, Park SQ et al: The neural code of reward anticipation in human orbitofrontal cortex. Proc Natl Acad Sci U S A. 2010; 107(13): 6010-6015. PubMed Abstract | Publisher Full Text | Free Full Text

Kanske P, Böckler A, Trautwein FM, et al.: Dissecting the social brain: Introducing the EmpaToM to reveal distinct neural networks and brain-behavior relations for empathy and Theory of Mind. Neuroimage. 2015; 122: 6-19.

PubMed Abstract | Publisher Full Text

Kapogiannis D, Barbey AK, Su M, et al:: Cognitive and neural foundations of religious belief. Proc Natl Acad Sci U S A. 2009; 106(12): 4876-4881. PubMed Abstract | Publisher Full Text | Free Full Text

Keysers C, Gazzola V: Social neuroscience: mirror neurons recorded in humans. Curr Biol. 2010; 20(8): R353-354.

PubMed Abstract | Publisher Full Text

Koenig H, King D, Carson VB: Handbook of religion and health. (2nd ed.). New York: Oxford University Press. 2012.

Reference Source

Kristjansson A, Campana G: Where perception meets memory: a review of repetition priming in visual search tasks. Atten Percept Psychophys. 2010; 72(1): $5-18$.

PubMed Abstract | Publisher Full Text

Krueger F, Grafman J: The neural basis of human belief systems. Hove, East Sussex; New York: Psychology Press, 2013.

Reference Source

Kuo WJ, Sjöström T, Chen YP, et al.: Intuition and deliberation: two systems for strategizing in the brain. Science. 2009; 324(5926): 519-522.

PubMed Abstract | Publisher Full Text

La Cour P, Hvidt NC: Research on meaning-making and health in secular society: secular, spiritual and religious existential orientations. Soc Sci Med. 2010; 71(7): 1292-1299.

PubMed Abstract | Publisher Full Text

Langdon R, Coltheart M: The cognitive neuropsychology of delusions. Mind Lang. 2000; 15(1): 184-218.

Publisher Full Text

Le Poidevin R, McBeath M (eds.): The Philosophy of Time. Oxford: Oxford University Press, 1993

Reference Source

Legare $\mathrm{CH}$, Nielsen M: Imitation and innovation: The Dual Engines of Cultural Learning. Trends Cogn Sci. 2015; 19(11): 688-699.

PubMed Abstract | Publisher Full Text

Leuthold $\mathrm{H}$, Kunkel A, Mackenzie IG, et al:: Online processing of moral transgressions: ERP evidence for spontaneous evaluation. Soc Cogn Affect Neurosci. 2015; 10(8): 1021-9.

PubMed Abstract | Publisher Full Text | Free Full Text

Levelt WJM: Speaking - from intention to articulation. MIT Press, 1993.

Reference Source

Markman KD, Proulx T, Lindberg ML: The Psychology of Meaning. Wash. DC American Psychological Association, 2013.

Publisher Full Text

Matsuzaka Y, Tanji J, Mushiake H: Representation of Behavioral Tactics and

Tactics-Action Transformation in the Primate Medial Prefrontal Cortex.

J Neurosci. 2016; 36(22): 5974-5987.

PubMed Abstract | Publisher Full Tex

Meder D, Haagsensen BN, Hulme O, et al:: Tuning the Brake While Raising the

Stake: Network Dynamics during Sequential Decision-Making. J Neurosci.

2016; 36(19): 5417-5426

PubMed Abstract | Publisher Full Text | Free Full Text

Mesulam MM: Large-scale neurocognitive networks and distributed processing

for attention, language, and memory. Ann Neurol. 1990; 28(5): 597-613.

PubMed Abstract | Publisher Full Text

Mesulam M: Representation, inference, and transcendent encoding in

neurocognitive networks of the human brain. Ann Neurol. 2008; 64(4): 367-378. PubMed Abstract | Publisher Full Text

Meyniel F, Schlunegger D, Dehaene S: The Sense of Confidence during Probabilistic Learning: A Normative Account. PLoS Comput Biol. 2015; 11(6): e1004305.

PubMed Abstract | Publisher Full Text | Free Full Text

Nachev P, Kennard C, Husain M: Functional role of the supplementary and presupplementary motor areas. Nat Rev Neurosci. 2008; 9(11): 856-869.

PubMed Abstract | Publisher Full Text

Niendam TA, Laird AR, Ray KL, et al:: Meta-analytic evidence for a superordinate cognitive control network subserving diverse executive functions. Cogn Affect Behav Neurosci. 2012; 12(2): 241-268.

PubMed Abstract | Publisher Full Text | Free Full Text

Ninaus M, Kober SE, Witte M, et al:: Neural substrates of cognitive control unde the belief of getting neurofeedback training. Front Hum Neurosci. 2013; 7: 914 PubMed Abstract | Publisher Full Text | Free Full Text

Northoff G: Self and brain: what is self-related processing? Trends Cogn Sci. 2011; 15(5): 186-187.

PubMed Abstract | Publisher Full Text

Nortmann N, Rekauzke S, Onat S, et al.: Primary visual cortex represents the difference between past and present. Cereb Cortex. 2015; 25(6): 1427-1440. PubMed Abstract | Publisher Full Text | Free Full Text

Oviedo L: Recent Scientific Explanations of Religious Beliefs: A Systematic Account. In: Angel H-F, Oviedo L, Paloutzian R F, Runehov A L C, Seitz R.J (Eds.). Process of Believing: The Acquisition, Maintenance, and Change in Creditions. Dordrecht, Heidelberg: Springer, in press. 2016. 
Paloutzian RF, Mukai KJ: Believing, Remembering, and Imagining: The Roots and Fruits of Meanings Made and Remade. In: Angel H-F, Oviedo L, Paloutzian R F, Runehov A L C, Seitz R.J (Eds.). Process of Believing: The Acquisition, Maintenance, and Change in Creditions. Dordrecht, Heidelberg: Springer, in press, 2016.

Reference Source

Paloutzian RF, Park CL: Directions for the future of psychology of religion and spirituality: research advances in methodology and meaning systems. In: Paloutzian RF, Park CL (eds) Handb Psychology Religion Spirituality. $2^{\text {nd }}$ edition, Guilford Press, 2013; 651-665.

Reference Source

Paloutzian RF, Park CL: Religiousness and spirituality: The psychology of multilevel meaning-making behavior. Religion Brain Behavior. 2015; 5(2): 166-178. Publisher Full Text

Pargament $\mathrm{KI}$ : Of means and ends: Religion and the search for significance. The Int J Psychology Religion. 1992; 2(4): 201-229.

Publisher Full Text

Park CL: Religion and meaning. In: Handb Psychology Religion Spirituality. Paloutzian RF, Park CL (eds) Guildford Press, New York, 2005; 295-314. Passingham RE, Bengtsson SL, Lau HC: Medial frontal cortex: from selfgenerated action to reflection on one's own performance. Trends Cogn Sci. 2010; 14(1): 16-21.

PubMed Abstract | Publisher Full Text | Free Full Text

Peters J, Büchel C: Overlapping and distinct neural systems code for subjective value during intertemporal and risky decision making. J Neurosci. 2009; 29(50): 15727-15734.

PubMed Abstract | Publisher Full Text

Potthoff D, Seitz RJ: Role of the first and second person perspective for control of behaviour: understanding other people's facial expressions.

J Physiol Paris. 2015; pii: S0928-4257(15)30003-6.

PubMed Abstract | Publisher Full Text

Prochnow D, Brunheim S, Kossack $\mathrm{H}$, et al:: Anterior and posterior subareas of the dorsolateral frontal cortex in socially relevant decisions based on masked affect expressions [version 1; referees: 2 approved with reservations]. F1000Res. 2015; 3: 212

PubMed Abstract | Publisher Full Text | Free Full Text

Radvansky GA, Zacks JM: Event Cognition. NY: Oxford University Press. 2014. Publisher Full Text

Roland PE, Mortensen E: Somatosensory detection of microgeometry, macrogeometry and kinaesthesia in man. Brain Res Rev. 1987; 12(1): 1-42. Publisher Full Text

Rolls ET: Brain mechanisms underlying flavour and appetite. Philos Trans $R$ Soc Lond B Biol Sci. 2006; 361(1471): 1123-1136.

PubMed Abstract | Publisher Full Text | Free Full Text

Roux F, Wibral M, Mohr HM, et al:: Gamma-band activity in human prefrontal cortex codes for the number of relevant items maintained in working memory. J Neurosci. 2012; 32(36): 12411-12420.

PubMed Abstract | Publisher Full Tex

Sasse LK, Peters J, Büchel C, et al:: Effects of prospective thinking on intertemporal choice: The role of familiarity. Hum Brain Mapp. 2015; 36(10): 4210-4221.

PubMed Abstract | Publisher Full Text

Schnell T: A framework for the study of implicit religion: the psychological theory of implicit religiosity. Implicit Religion. 2003; 6(2): 86-104.

Publisher Full Text

Schnell T: Spirituality with and without religion. Arch Psychol Religion. 2012; 34(1): 33-62.

Publisher Full Tex

Schnell T, Keenan WJF: Meaning-making in an atheist world. Arch Psychol

Religion. 2011; 33(1): 55-78.

Publisher Full Text

Schultze-Kraft M, Birman D, Rusconi M, et al:: The point of no return in vetoing self-initiated movements. Proc Natl Acad Sci U S A. 2016; 113(4): 1080-1085 PubMed Abstract | Publisher Full Text | Free Full Text

Schwartenbeck P, FitzGerald THB, Dolan R: Neural signals encoding shifts in beliefs. Neuroimage. 2016: 125: 578-586.

PubMed Abstract | Publisher Full Text | Free Full Text

Seitz RJ, Angel HF: Psychology of Religion and Spirituality: Meaning Making and processes of believing. Religion Brain Behav. 2015; 5(2): 139-147.

Publisher Full Text

Seitz RJ, Franz M, Azari NP: Value judgments and self-control of action: the role of the medial frontal cortex. Brain Res Rev. 2009; 60(2): 368-378.

PubMed Abstract | Publisher Full Text

Seitz RJ, Nickel J, Azari NP: Functional modularity of the medial prefrontal cortex: involvement in human empathy. Neuropsychology. 2006; 20(6): 743-751. PubMed Abstract | Publisher Full Text

Seligman R, Brown RA: Theory and method at the intersection of anthropology and cultural neuroscience. Soc Cogn Affect Neurosci. 2010; 5(2-3): 130-137. PubMed Abstract | Publisher Full Text | Free Full Text

Sharan L, Rosenholtz R, Adelson EH: Accuracy and speed of material categorization in real-world images. J Vis. 2014; 14(9): pii: 12

PubMed Abstract | Publisher Full Text | Free Full Text

Smith ML: Rapid processing of emotional expressions without conscious awareness. Cereb Cortex. 2012; 22(8): 1748-1760.

PubMed Abstract | Publisher Full Text

Stich S: From Folk Psychology to Cognitive Science. The Case against Belief. 2nd Ed., Cambridge Massachusetts, 1996.

Sugiura M, Seitz RJ, Angel HF: Models and neural bases of the believing process. JBBS. 2015; 5: 12-23.

Publisher Full Text

Takei S, Nishida S: Perceptual ambiguity of bistable visual stimuli causes no or little increase in perceptual latency. J Vis. 2010; 10(4): 23.1-15.

PubMed Abstract | Publisher Full Text

Taves A: Reverse engineering complex cultural concepts: Identifying building blocks of "religion". J Cogn Culture. 2015; 15(1-2): 191-216.

Publisher Full Text

Thompson R, Duncan J: Attentional modulation of stimulus representation in human fronto-parietal cortex. Neuroimage. 2009; 48(2): 436-448.

PubMed Abstract | Publisher Full Text

van Gaal S, Scholte HS, Lamme VA, et al:: Pre-SMA graymatter density predicts individual differences in action selection in the face of conscious and unconscious response conflict. J Cogn Neurosci. 2011; 23(2): 382-390. PubMed Abstract | Publisher Full Text

Van Overwalle F: Social cognition and the brain: a meta-analysis. Hum Brain Mapp. 2009; 30(3): 829-858.

PubMed Abstract | Publisher Full Text

Visela A, Angel HF: The theory of credition and philosophical accounts of belief: looking for common ground. In: Angel H-F, Oviedo L, Paloutzian R F, Runehov A L C, Seitz R.J (Eds.). Process of Believing: The Acquisition, Maintenance, and Change in Creditions. Dordrecht, Heidelberg: Springer, in press. 2016 .

Reference Source

Vogeley K, Roepstorff A: Contextualising culture and social cognition. Trends Cogn Sci. 2009; 13(12): 511-516.

PubMed Abstract | Publisher Full Text

Wang C, Oyserman D, Liu Q, et al:: Accessible cultural mind-set modulates default mode activity: evidence for the culturally situated brain. Soc Neurosci. 2013; 8(3): 203-216.

PubMed Abstract | Publisher Full Text

Wiese E, Wykowsky A, Müller $\mathrm{HJ}$ : What we observe is biased by what other people tell us: beliefs about the reliability of gaze behavior modulate attentional orienting to gaze cues. PLoS One. 2014; 9(4): e94529.

PubMed Abstract | Publisher Full Text | Free Full Text 


\section{Open Peer Review}

\section{Current Peer Review Status:}

\section{Version 1}

Reviewer Report 19 December 2016

https://doi.org/10.5256/f1000research.10535.r18600

(C) 2016 Schnell T et al. This is an open access peer review report distributed under the terms of the Creative Commons Attribution License, which permits unrestricted use, distribution, and reproduction in any medium, provided the original work is properly cited.

\section{Tatjana Schnell}

Institute of Psychology, University of Innsbruck, Innsbruck, Austria

\section{Roberto Viviani}

${ }^{1}$ Innsbruck University, Innsbruck, Austria

2 Psychotherapy Clinic, University of UIm, Ulm, Germany

The authors provide a broad introduction to a novel theoretical concept, the process of believing. It is complemented by references to empirical findings that lend support to the theoretical claims. The concept's usefulness for neuroscience and anthropology, in particular, is discussed.

As the authors note, the act, or process, of believing has largely been ignored by scholars. While psychology offers insights into both cognition and emotion, believing seems not to be well covered by these theories. The authors suggest defining processes of believing as probabilistic representations, associated with specific personal meaning and value. Rooted in neural processes, processes of believing are proposed to guide human behaviour.

The endeavour is topical and worthwhile, since much of our proposed knowledge is actually belief, and clear differentiation between both will be fruitful. Furthermore, belief is all too often associated with the realm of the supernatural, and thus viewed as something that is only of concern for studies of religion, etc. But believing is widespread, also in mundane everyday life, as the authors suggest.

In some places, the text might benefit from more coherence. In the first section, e.g., we had the sense that the provided list of definitions is of no consequence for the rest of the manuscript.

Due to the novelty of the research subject, the terminology is of special importance. The authors call "normal belief" a "brain product" linked to personal intuitive judgements about the subjective certainty of mental constructs and sensory perceptions. The term "normal belief" might not be the best choice of term, since it seems to refer to something normative, or some belief held by the majority of people (thus being normal). 
The reader is also left wondering about the relationship between "belief" as in "predictions about the next event", or judgments where religious issues play no role, and religious belief. If the purpose of the term "normal belief" is to root religious belief into belief as a more general cognitive process, it should be renamed accordingly and more explicitly.

The process of perception is described as resulting in "comprehending the object's features" (p. 4), and, later, as resulting "in a meaningful illusion" (p. 4). The two descriptions seem to contradict each other; instead of calling the outcome an illusion, it might better be viewed as a "Gestalt", i.e. a meaningful perception that provides clues for action to follow ${ }^{1,2}$.

Starting from page 4, the authors review neural circuits of stimulus perception, stimulus valuation (including its emotional tone) and decision making. The authors propose that this circuit underlies belief formation ("personal probabilistic representations").

It should be noted that the neuroscience they refer to here deals with predictions about events whose valuation, and consequent motivational effects, are entirely utilitarian ${ }^{3,4}$. The purported computational processes associated with these networks concern prediction of rewarding or aversive outcomes (probabilistic predictions of reward or fear of punishment, p. 8). This leaves the reader wondering if this has the consequence that there is nothing specific about religious beliefs, relative to other utilitarian or adaptive cognitive-behavioural strategies. The ventromedial prefrontal cortex, where, as the authors note, complex properties of stimuli ${ }^{5-8}$ or the context of their presentation ${ }^{9}$ may be integrated to compute stimulus valuation and its emotional quality ${ }^{10}$ has been touted as the neurological machinery that allows consistent decision making, in effect computing utilities as in the economic understanding of this term ${ }^{4,11}$.

It is interesting to conjecture that these same networks could be the starting point of beliefs, but the evidence does not imply this in any straightforward manner. If predictions are beliefs also Pavlov's dog was 'believing' after hearing the bell. Importantly, one may not be conscious of anticipating anything but still bear the motivational consequences of these unconscious predictions $^{12}$, as when presented with conditioned cues subliminally. An issue that seems to be relevant in this respect is that these networks are very likely not monolithic (as the authors themselves note in commenting Figure 2), but are thought to involve parallel valuation and decision mechanisms, associated with different strategies to process the inputs and compute response ${ }^{13}$. But then one would expect the notion of belief to be explicated in terms that are more specifically relevant for some, but not all, of these mechanisms.

Previous functional neuroimaging of generic beliefs ${ }^{14-15}$ or of beliefs that are more specifically religious ${ }^{16}$ raise the issue of whether cognitive decision making bears the traces of different strategies to arrive to a response, associated with different brain networks. This may be particularly relevant for beliefs, as there is good reason to single out those cognitive decisions that are marked by bias. The ventromedial prefrontal cortex seems again to play an important role in this respect $11,14,17$, as an important hypothesis is that beliefs may be a specific class of intuitive, pre-evidential judgments, demonstrably produced when a specific part of the valuation-decision making network gains the upper hand. The relationship of religious belief with biased judgment seems important, but is an issue that the manuscript leaves entirely open.

Several findings also implicate the amygdala in choices where emotions and intuitions play an important role 17,18 . Considering the role of neural substrates directly linked to emotion when 
choosing between sources of meaning could add to the bigger picture of how acts of believing are linked to non-rational processes. Decision making between potential sources of meaning such as religion/spirituality, nature, community, may be related to the affective network in the brain, but not to more refined goal-directed mechanisms in the prefrontal cortex, as is suggested by a recent study ${ }^{19}$.

On a psychological level, further construct clarification could ensue from discussing relationships between processes of believing and intuition. Research findings on intuition ${ }^{20}$ might help to better understand processes of believing, and to identify the boundaries between both.

Minor points:

Schnell, $2003^{21}$ is quoted as suggesting that "humans are born with an implicit religiosity" (p. 6). This seems to be a misreading of the publication, which aims to clarify in which cases implicit religiosity is present: "All those contents which are structured as myth, ritual or transcendent experience, and evaluated as meaningful by an individual, can be said to constitute implicit religiosity" (p. 89). Not every person is implicitly religious, and it is not an inborn characteristic although the propensity to elevate what is personally meaningful, and to express it by means of stories, rituals, and extraordinary experiences that go beyond the rational, appears to be common to all humans.

Why does a process of believing necessarily have to have a start and a closure, as suggested by the authors?

\section{References}

1. Schnell T: The Sources of Meaning and Meaning in Life Questionnaire (SoMe): Relations to demographics and well-being. The Journal of Positive Psychology. 2009; 4 (6): 483-499 Publisher Full Text

2. Schnell T: Psychologie des Lebenssinns. Springer. 2016.

3. Rangel A, Camerer C, Montague PR: A framework for studying the neurobiology of value-based decision making.Nat Rev Neurosci. 2008; 9 (7): 545-56 PubMed Abstract | Publisher Full Text 4. Levy DJ, Glimcher PW: The root of all value: a neural common currency for choice.Curr Opin Neurobiol. 2012; 22 (6): 1027-38 PubMed Abstract | Publisher Full Text

5. O'Doherty JP: Lights, camembert, action! The role of human orbitofrontal cortex in encoding stimuli, rewards, and choices.Ann N Y Acad Sci. 2007; 1121: 254-72 PubMed Abstract | Publisher Full Text

6. Chib VS, Rangel A, Shimojo S, O'Doherty JP: Evidence for a common representation of decision values for dissimilar goods in human ventromedial prefrontal cortex.J Neurosci. 2009; 29 (39): 12315-20 PubMed Abstract | Publisher Full Text

7. Smith DV, Hayden BY, Truong TK, Song AW, et al.: Distinct value signals in anterior and posterior ventromedial prefrontal cortex.J Neurosci. 2010; 30 (7): 2490-5 PubMed Abstract | Publisher Full Text

8. Lim SL, O'Doherty JP, Rangel A: Stimulus value signals in ventromedial PFC reflect the integration of attribute value signals computed in fusiform gyrus and posterior superior temporal gyrus.J Neurosci. 2013; 33 (20): 8729-41 PubMed Abstract | Publisher Full Text

9. Wilson RC, Takahashi YK, Schoenbaum G, Niv Y: Orbitofrontal cortex as a cognitive map of task space.Neuron. 2014; 81 (2): 267-79 PubMed Abstract | Publisher Full Text 
10. Roy M, Shohamy D, Wager TD: Ventromedial prefrontal-subcortical systems and the generation of affective meaning.Trends Cogn Sci. 2012; 16 (3): 147-56 PubMed Abstract | Publisher Full Text

11. Plassmann $\mathrm{H}, \mathrm{O}$ 'Doherty J, Rangel A: Orbitofrontal cortex encodes willingness to pay in everyday economic transactions.J Neurosci. 2007; 27 (37): 9984-8 PubMed Abstract | Publisher Full Text

12. LeDoux JE: Coming to terms with fear.Proc Natl Acad Sci U S A. 2014; 111 (8): 2871-8 PubMed Abstract | Publisher Full Text

13. Daw N, O'Doherty J: Multiple Systems for Value Learning. 2014. 393-410 Publisher Full Text 14. Goel V, Dolan RJ: Explaining modulation of reasoning by belief.Cognition. 2003; 87 (1): B11-22 PubMed Abstract

15. Harris S, Sheth SA, Cohen MS: Functional neuroimaging of belief, disbelief, and uncertainty.Ann Neurol. 2008; 63 (2): 141-7 PubMed Abstract | Publisher Full Text

16. Harris S, Kaplan JT, Curiel A, Bookheimer SY, et al.: The neural correlates of religious and nonreligious belief.PLoS One. 2009; 4 (10): e0007272 PubMed Abstract | Publisher Full Text 17. De Martino B, Kumaran D, Seymour B, Dolan RJ: Frames, biases, and rational decision-making in the human brain.Science. 2006; 313 (5787): 684-7 PubMed Abstract | Publisher Full Text 18. Seymour B, Dolan R: Emotion, decision making, and the amygdala.Neuron. 2008; 58 (5): $662-71$ PubMed Abstract | Publisher Full Text

19. Viviani R, Dommes L, Beschoner P, Stingl J, et al.: Choosing between human values and food: the Pavlocian substrates of intrinsic preferences. 14th Annual Conference of the Society of Neuroeconomics. 2016.

20. Gigerenzer G: Gut feelings: The intelligence of the unconscious. Penguin. 2007.

21. Schnell T: A Framework for the Study of Implicit Religion: The Psychological Theory of Implicit Religiosity. Implicit Religion. 2007; 6 (2). Publisher Full Text

Competing Interests: No competing interests were disclosed.

We confirm that we have read this submission and believe that we have an appropriate level of expertise to confirm that it is of an acceptable scientific standard.

Author Response ( ) 06 Jan 2017

Rudiger Seitz, LVR-Klinikum Düsseldorf, Düsseldorf, Germany

We thank the reviewers for their constructive comments and thoughtful questions concerning a number of aspects in our manuscript that stimulated us to engage in further clarifying these points. We will detail successively the corresponding changes we made in the manuscript as follows:

As suggested we reviewed the first section carefully and rephrased it to enhance the visibility of coherence within the section and with respect to the rest of the paper.

We explain that the notion of "normal belief" is usually contrasted to its pathological manifestations in brain diseases (page 4). In accordance with the reviewer dropped this expression from the manuscript, since it may cause associations mentioned by the reviewers which were not intended.

We now are more specific concerning the questioned relation of "belief" and religious belief. 
We do not want to expand on the adjective "religious" which is ambiguous as we have outlined elsewhere (Angel and Seitz 2016). With respect to the question of the reviewer and for improved clarity we transposed paragraphs in the final section and now state on page 20 of the revised manuscript that "religious belief" in the sense of "non-secular belief" and "secular belief" are hypothesized to be brought forward by similar, if not identical processes of believing but that they differ by their specific contents. In fact, they differ by narratives as we state on page 19. Please, note that believing is considered a fundamental brain process entirely separate from religious beliefs as stated explicitly on page 20 .

We are entirely happy with the suggestion of the reviewers to refer to "Gestalt". This notion was developed by von Weizsäcker in the 40ies of last century. To his work we now refer in the revised manuscript on page 11.

With respect to the discussion about prediction we would like to point out that believing and beliefs should not be reduced to prediction. We now state on page 14 that believing pertains to experience, i.e. knowledge acquired in the past. Moreover, we outline that believing links the past to the future as it allows the individual to make predictions (pages $12,14)$. For example, acquired knowledge and predictions work on the physical world being entirely probabilistic. This becomes apparent by the automatic unconscious servo control of the hand for object grasping (Diamond et al, Pélisson et al; not cited on page 12). Likewise the meaning a subject attributes to an object or event reflects his/her prior experience with such an object or event providing a basis for estimating its future implication; specifically, the question is whether the object or event is beneficial or satisfying for the subject or adverse or deleterious (page 14). Finally, decision making is consistent only as long as a belief has not been modified in response to new and violating information. This topic is explained in greater detail elsewhere (Angel and Seitz 2017) now cited on page 21.

The comment about Pavlows reflex is noteworthy. As the reviewer points out, this is a subconscious process that cannot be influenced voluntarily by the subject. And certainly the onset of salivation induced by the conditioning ringing of a bell reflects an automatic prediction. We can exaggerate this argument extending it to all types of reflexes including the eyelid reflex and the muscle tendon reflexes: the neuronal machinery operates with the goal to protect the integrity of the organism against predicted harm or to prepare it optimally for an upcoming action. If we accept this, we may want to argue that even the basic neural circuits are equipped with a machinery that internalizes sensory experience to code for appropriate behaviour for integrity and survival of the organism. Higher cognitive and emotional functions that constitute believing are more complex working in parallel cortico-cortical and cortico-subcortical circuits in the human brain. These complex brain systems are suited to afford the integrity and survival of the individual human and of groups of humans including societies as we now state on page 21.

We agree that beliefs are based on intuitive pre-evidential and probabilistic judgments. We now state on page 20 that rituals are likely to bias humans to accept narratives as beliefs held in social groups as well as in secular and religious faith groups.

Decision making is a brain function following and engaging judgments and predictions. In other words, decision making is down the road with respect to believing. We absolutely 
agree that different types of information processed in parallel and highly interconnected brain circuits come into play. The point we would like to make, however, is that the interface for such complex self-oriented computations seems to be the medial prefrontal cortex that comprises multiple functional units as evident from Figure 2 and outlined in greater detail elsewhere (Seitz et al. 2006, van Overwalle 2009). We now emphasize this issue on page 16 and refer to it later in the manuscript again (page 21).

We are grateful about the clarification concerning the notion of implicit religiosity and modified this phrase accordingly (page 23).

In our empirical model we use the novel sensory stimulus as starting point of the believing process and the establishment of a probabilistic representation as the endpoint of the believing process. This has now been stated clearly on page 11 . However, as write on page 21 new experiences constantly entertain an update of such a representation reflecting the potentially fluid nature of beliefs.

Competing Interests: No competing interests were disclosed.

Reviewer Report 21 November 2016

https://doi.org/10.5256/f1000research.10535.r17817

(c) 2016 Halligan P et al. This is an open access peer review report distributed under the terms of the Creative Commons Attribution License, which permits unrestricted use, distribution, and reproduction in any medium, provided the original work is properly cited.

\section{Peter W. Halligan}

Learned Society of Wales (LSW), Cardiff, UK

\section{Michael H. Connors}

Department of Cognitive Science, Macquarie University, Sydney, NSW, Australia

In this paper, the authors discuss the notion of belief and its explanatory role across a wide range of academic disciplines. These include, for example, psychology, religion, philosophy,

anthropology, and cognitive neuroscience. The authors aim to demonstrate that believing is a core function of the brain that guides much of our behaviour. They also argue that these cognitive processes operate in narratives and rituals across both religious and secular contexts. To address these goals, the authors provide a brief, if sometimes dense, discussion of belief, which includes the history and philosophy of the concept, the role of belief in anthropology and neuroscience, and belief's more specific functions in religion, rituals, and narratives.

The paper provides an interesting contribution to a historically neglected area of psychology and cognitive neuroscience, namely understanding and characterising the nature of belief. That said, the paper is perhaps too ambitious in scope, covering many different topics - including a conceptual history of belief and the role of belief in areas such as philosophy, religion, anthropology, perception, and cognitive neuroscience. Consequently, the paper at times appears 
a little unfocused and difficult to follow. It could be improved by having a clearer structure and possibly outlining how the various sections contribute to the central goals of the paper. Given the breadth of coverage, many of the topics cannot be covered in the detail they deserve. One could argue, given the authors' central argument, that much of the historical review - including the sections on the history and philosophy of belief - could be omitted without detracting from the main purpose of the paper.

The main focus of the paper remains the anthropology and cognitive neuroscience of belief. The authors here outline four levels of explanation for understanding belief - hermeneutic, linguistic, behavioural, and neurophysiological. These levels of explanation are not, however, always fully justified. It is not clear, for example, what the distinction between the hermeneutic and linguistic is and also whether the behavioural level can be necessarily grouped with the cognitive. It also remains unclear how the levels of explanation inform the rest of the paper.

In one particular section, the authors discuss the importance of perception. Specifically, they note "To understand the process of believing, it is essential to understand how people attribute personal meaning to specific sensory perceptions" (p. 4). The authors then provide a description of the processes involved in perceiving the physical characteristics of stimuli and the processes involved in attributing affective value and meaning. This important section could be expanded to include more evidence in support of the claims being put forward. In its current form, it is unclear how much is intended as a description of fact and how much involves the authors' own theoretical take.

The section on neuroscience is also important to the authors' central thesis. The authors outline a model of believing as involving different brain regions. As this is possibly one of the most novel and significant parts of the paper, this section would benefit by being expanded to provide more details. For example, the authors make several claims about the role of different brain regions for selective cognitive functions (e.g., they suggest that valuation of perceived objections and attributions involves the medial frontal cortex) and then cite papers without much further explanation. The authors should engage more with the literature that they cite and explain how the research support their claims. They could also outline their model more clearly and how it relates to belief overall (rather than just sub-component processes, like the valuation of percepts).

A further issue in these sections that could be addressed is that it is not clear whether the authors reach their overall goal. They state in the paper's abstract: “We present evidence suggesting that believing is a human brain function which results in probabilistic representations with attributes of personal meaning and value and thereby guides individuals' behaviour" (p. 1). However, much of these sections on perception and neuroscience is descriptive and, as already noted, relies on citations of previous papers without further explanation of how these support their claims. The authors could more specifically highlight what they consider to be evidence for their model and discuss more critically how it supports their account.

In the final section, the authors turn to belief systems in religion, rituals, and narratives. The authors here suggest that similar belief processes are common across both religious and secular contexts. It is not clear, however, why people would doubt this idea in the first place. The discussion, like other sections, contains some interesting material, but again is limited somewhat by selective engagement with existing literature. For example, the authors suggest "because 'religion' is not one thing but many, it is better to talk about specific religions, because almost no statement about what 'religion' does will hold for all of them" (p. 6), then appear to make general 
claims about religion, religiosity, and religious experience. Apart from this apparent inconsistency, it is unclear whether this is a consensus opinion by all religious scholars. Other minor examples include claims about how "humans are born with an "implicit religiosity" (p. 6) and that rituals" constitute the experience and knowledge and, thereby, the belief systems of individuals from childhood onwards" (p. 7), where it is similarly unclear how established these claims are.

In sum, the paper addresses an important and timely topic, and presents proposals for a potentially novel perceptual/neural model for understanding belief. The paper, however, would benefit by focusing and clarifying its underlying purpose and reducing the breadth of coverage. The paper could also be improved by discussing the evidence and arguments supporting their central claims in greater detail.

Competing Interests: No competing interests were disclosed.

We confirm that we have read this submission and believe that we have an appropriate level of expertise to confirm that it is of an acceptable scientific standard, however we have significant reservations, as outlined above.

Author Response ( ) 06 Jan 2017

Rudiger Seitz, LVR-Klinikum Düsseldorf, Düsseldorf, Germany

We appreciate the constructive comments of the reviewers which helped us to revise our manuscript as we explain in the following point-to-point response.

According to their suggestion we rephrased the Introduction to outline more clearly how the various sections contribute to the goal of this paper. Furthermore, the section about the history and philosophy of belief was shortened and rephrased with a couple of additional citations to highlight our standpoint.

We now have introduced further explanations to make clear the different levels of exploration such as the hermeneutic, linguistic, behavioral and the cognitive level to define the process of believing (page 5).

Following the suggestions of the reviewers we have expanded our description about the physiological basis of perception and probabilistic coding (pages 12, 13, 14). Also, we now spell out more clearly our standpoint to this theoretical matter (page 10). Admittedly, however, we can only sketch out the topics relevant for our discussion (page 14), while a comprehensive review of the literature would go beyond the limits of this opinion paper.

We substantiated the relation of the references to our manuscript and describe that a number of physiologically well described processes are essential for the processes of believing. We do not claim that they are exclusive. But in our view empirical evidence provides the framework for their contribution to the processes of believing as we now state explicitly on pages 5 .

We have rephrased the criticized statements about religion, religiosity and religious experience (page 20). Also, we introduced appropriate references in the final section to 
substantiate our claims.

Competing Interests: No competing interests were disclosed.

Reviewer Report 08 November 2016

https://doi.org/10.5256/f1000research.10535.r17438

(c) 2016 Suguira M. This is an open access peer review report distributed under the terms of the Creative Commons Attribution License, which permits unrestricted use, distribution, and reproduction in any medium, provided the original work is properly cited.

\section{Motoaki Suguira}

Institute of Development, Aging and Cancer (IDAC), International Research Institute of Disaster Science (IRIDeS), Tohoku University , Sendai, Japan

This is a good comprehensive review and model of the scientific status of the religious and secular belief or believing process.

Major point:

It would be more helpful for the readers if there was emphasis on what is the key aspects of the current model that makes it new and different from previous models of the authors or other researchers.

Minor point:

While the two figures have very similar format, in the figure 1 there is a specific quantity of the time (i.e. 40ms) but not in the figure 2; the former looks a kind of experimental data and the latter a conceptual schema. It may be better to clarify whether two figures are similar or very different in terms of the roles in the manuscript (i.e. data or schema).

Competing Interests: No competing interests were disclosed.

I confirm that I have read this submission and believe that I have an appropriate level of expertise to confirm that it is of an acceptable scientific standard.

Author Response ( ) 06 Jan 2017

Rudiger Seitz, LVR-Klinikum Düsseldorf, Düsseldorf, Germany

We thank the reviewer for his comments and now make clear on page 14 what the specific aspects of our model of believing are as compared to previous accounts.

We assume that for some reason the time scale was not in the print-out of Figure 3 . We absolutely agree that a time scale is important for this figure, since in contrast to Figure 1 the scale goes over years. We respectfully submit that the scale is shown in the figure. 
Competing Interests: No competing interests were disclosed.

The benefits of publishing with F1000Research:

- Your article is published within days, with no editorial bias

- You can publish traditional articles, null/negative results, case reports, data notes and more

- The peer review process is transparent and collaborative

- Your article is indexed in PubMed after passing peer review

- Dedicated customer support at every stage

For pre-submission enquiries, contact research@f1000.com 